\title{
Teacher Positioning and Students with Dyslexia: Voices of Croatian EFL teachers
}

\author{
Agnieszka Kałdonek-Crnjaković ${ }^{1}$, Zrinka Fišer ${ }^{2}$ \\ ${ }^{1}$ University of Warsaw, Poland \\ ${ }^{2}$ University of Slavonski Brod, Croatia \\ Correspondence concerning this article should be addressed to Agnieszka Kałdonek-Crnjaković, Institute \\ of English Studies, University of Warsaw, ul. Hoża 69, 00-681 Warsaw, Poland. \\ E-mail: a.kaldonek2@uw.edu.pl
}

\begin{abstract}
How students with dyslexia are positioned by their language teachers and what roles teachers assume when working with this group of students have rarely been investigated. In this study, using positioning theory as a theoretical framework and collecting data by means of an indepth semi-structured interview and lesson observations, which were subsequently coded, we enquired about the positioning of 10 in-service Croatian primary and secondary school teachers. We wanted to know how teacher participants positioned students with dyslexia and how they positioned themselves towards this group of students. The analysis revealed that participants expressed positive attitudes, whereas their positioning was diverse. Participants positioned themselves as caring teachers and teachers of all learners. By recognising various learner needs, they created an inclusive learning environment by adapting teaching approaches and providing accommodations. However, this caring resulted in emotion labour, with both emotional costs and rewards. These results imply that teaching students with dyslexia may be challenging, and we hope that discussing teacher positioning in this context can help educators better understand teacher agency when working with students with SpLDs.
\end{abstract}

Keywords: dyslexia, language teachers, teacher agency, teaching-as-caring, emotion labour, positioning theory

\section{Introduction}

Positioning theory allows for describing processes of "conversations of speech and action that are labile, contestable and ephemeral" (Harré \& Moghaddam, 2015, p. 229). It has been used as a theoretical framework in education and applied linguistics research in the past decade (Kayi-Aydar \& Miller, 2018), yet, it is still recent and limited in its applications (Kayi-Aydar, 2019). With the growing focus on the teacher (Mercer \& Kostoulas, 2018), investigating teacher positioning is important because students' engagement in the class and the content of the lesson may depend on it. Through teacher positioning, students will see how they fit in the classroom (Hazari et al., 2015).

Positioning can be approached from two perspectives. The first one is intentional self-positioning, that is "reflexive positioning in which one positions oneself", viewing the world from a specific position, which further guides how individuals act and what roles they choose to play in a given context (Davies \& Harré, 1990, p. 48). It is displayed in the individual's different discursive practices, which reflect one's "thoughts, feelings, intentions, plans" (Harré \& van Langenhove, 1999, p. 5). Teachers can either position themselves as teachers for students with various needs or as teachers who focus on regular students, and the position they have chosen will guide their interactive approaches with students (Yoon, 2008). However, using positioning as an analytical tool helps researchers and teachers identify learning opportunities that are crucial for second language students (Kayi-Aydar, 2014).

The other perspective is interactive positioning, "in which what one person says positions another" (Davies \& Harré, 1990, p. 48). However, one's utterances, actions, and thoughts have "a variety of meaning depending on who is using it, where, and for what" (Harré \& Moghaddam, 2015, p. 230). Thus, interactive positioning may be 
implicitly or explicitly precarious because of its potential negative effect (Sabat, 2003). In the classroom setting, teachers can assume numerous clustered positions (Soreide, 2006), and the teaching approaches they adopt position their students, either intentionally or unintentionally, in a more positive or more negative light (Yoon, 2008). For example, in Reeves' study (2009), the teacher participant regarded himself as a teacher of all students; yet, he refused to provide accommodations for students new to English to facilitate language learning. Foreign language teachers in Gkonou and Miller's study (2019) recognised their students' disruptive and problematic behaviour, not as something adverse, but as a sign of anxiety. They responded by employing anxiety-mitigating learning and teaching strategies and providing a range of adjustments and accommodations.

From the poststructural perspective, individuals' discourses and actions are shaped by their different selves, and positioning is used to gauge dynamic and complex aspects of the self (Kayi-Aydar, 2015). Naturally, therefore, teacher positioning is also closely linked to teacher agency, which "aims to describe teachers' efforts to make choices within a host of contexts" (White, 2018, p. 196); therefore, one influences the other (KayiAydar, 2015). It is thus complex and dynamic. Since agency may be mediated by many contextual factors, such as social, interactional, cultural, and institutional (van Lier, 2008), actions taken by the teacher may or may not be possible to realise (Lantolf \& Thorne, 2007). In other words, the teacher exercises their agency more in one context but less in another one (Kayi-Aydar, 2015), and when their actions are constrained, a teacher may assume a reflexive position to deal with constraints (White, 2018).

However, reflexive teacher positioning is not independently constructed (van Langenhove \& Harré, 1999). Gkonou and Miller (2019), for example, stress that teachers' narrative accounts cannot be easily predicted even when teachers are regarded as caring and responsible. Teachers' reflexive positioning will hinge on their personal past experiences and on the extent to which they are dependent on social norms, and how they construct themselves within these norms. Caring entails "attentiveness, trust, responsiveness to need, narrative nuance, and cultivating caring relations" (Held, 2006, p. 15). Since individuals are viewed as relational and interdependent, everyone involved should benefit equally (Held, 2006). According to Kumaravadivelu (2012), this relational approach to caring is most needed in today's language classroom because teachers regularly face difficult situations that stem from individual learner differences.

Caring, closely related to labour of emotions (Gkonou \& Miller, 2019; Koster, 2011), is the management of one's emotions that occur in a workplace (Hochschild, 1983). Since it is present in everyday aspects of teaching (Isenbarger \& Zembylas, 2006; Koster, 2011), teachers may incur many emotional costs. These costs are sometimes not easily noticeable, and thus stay unrecognised. Consequently, caring may be assumed as an innate part of teaching, and thus considered to be effortless (Isenbarger \& Zembylas, 2006).

This labour allows teachers to develop their agency in light of ethical self-formation, that is ongoing efforts to become better teachers (Gkonou \& Miller, 2019). However, from the poststructural perspective, as teacher emotions are shaped by personal, social, and political processes (Zembylas, 2002), this ethical self-formation may require teachers to control negative emotions and display only the positive ones that show caring (Isenbarger \& Zembylas, 2006) to maintain their professional identity, which may be shaped by expectations of workplace rules (Benesch, 2012, 2018). Thus, caring is challenging because the social situations teachers need to function in are very complex (Collins \& Ting, 2014). As Kumaravadivelu (2012, p. 66) explains it, teachers "are often confronted with a seemingly difficult choice between caring about their students and abiding by rules they are expected to enforce." Consequently, teachers may be expected to display only organisationally favoured emotions. This can be mentally tiring for them and lead to their self-estrangement, depersonalisation, and burnout (Acheson et al., 2016; King, 2015).

Drawing further on the poststructural perspective, emotions should not be divided into positive and negative categories because they are "potential sources of language-teacher agency" (Benesch, 2018, p. 61). As evidenced by some studies (Isenbarger \& Zembylas, 2006; Miller \& Gkonou, 2018), teachers, on the one hand, associate their teaching experience with frustration, anxiety, irritation, and disillusion; and on the other hand, they experience many positive emotions such as enthusiasm, happiness, caring, and satisfaction, which may serve as emotional rewards, provided their working conditions allow (Hargreaves, 2000). Therefore, Benesch (2020, p. 39) introduced the term "emotion labour" to emphasise "the relationship between emotions and power rather than qualifying the labor as emotional." Emotion labour may thus serve as a source of teacher activism (Benesch, 
2020). The term "emotion labour" has been used by many authors in their recent works on language teachers' emotions (e.g. Acheson et al., 2016; Benesch, 2017; Miller \& Gkonou, 2018).

Studies have showed that language teachers have been regarded as caring when they feel responsible for the success of all children (Kayi-Aydar, 2015), teach appropriate strategies that helped students reduce their language anxiety (Gkonou \& Miller, 2019), motivate students to learn (Chernobilsky et al., 2015) and respond to their various cultural and social needs (Yoon, 2008). Thus, teaching-as-caring (Miller \& Gkonou, 2018) considers the student as a whole; the teacher responds to their students' academic and social needs in an inclusive classroom, where all children feel accepted, take risks comfortably while learning, and find common ground to work as a group while accepting individual differences (Isenbarger \& Zembylas, 2006). However, responding to others' needs is never costless. It may be challenging to manage teacher anxiety that is caused by working conditions (Gkonou \& Miller, 2019), or when it results from feelings of failure and a lack of agentic position, as not all students' needs can be met in a large class (Kayi-Aydar, 2015).

Caring about the academic and social needs of those with SpLDs, such as dyslexia, can be demanding. Reading and writing difficulties that feature dyslexia may make learning an additional language more challenging. Consequently, learners with dyslexia frequently experience failure in language learning (Kormos, 2017; Nijakowska, 2010). These difficulties and limited successes cause a higher level of language anxiety (PiechurskaKuciel, 2008; Sparks \& Ganschow, 1991) and lower motivation for learning languages (Kormos \& Csizér, 2010) among learners with dyslexia. These affective factors may also be exacerbated by negative teacher attitudes and the use of inadequate teaching methods (Kormos et al., 2009).

The literature suggests that those who work with students with dyslexia should assume the position of a supportive and caring teacher. A teacher needs to recognise each student's learning potential (Nijakowska, 2010) by considering their strengths and weaknesses (Kormos \& Smith, 2012). They need to employ appropriate teaching approaches and accommodations (Nijakowska, 2010) and use motivational teaching strategies (Kormos et al., 2009). But to do so appropriately, teachers need to have a good understanding of the nature of learning difficulties and how they affect additional language learning (Kormos \& Kontra, 2008).

Research exploring teacher positioning in the context of dyslexia and other SpLDs is scarce. It rarely draws on the poststructural perspective by showing the dynamism of the complexity of teacher agency referring to teaching-as-caring and emotion labour. A study by Kormos and Kontra (2008) is an example. The researchers found that teacher participants believed that learners with dyslexia could successfully learn a foreign language when appropriate teaching and motivational approaches are adopted. A teacher's caring attitude was reflected in their understanding of a student's individual cognitive profile and the reasons for their misbehaving and lack of confidence, as well as by providing additional help and adjusting their teaching methods, for example. Such teacher behaviour is "enlightened" (p. 209) and thus relates to ethical self-formation, where the teacher makes ongoing efforts to improve their teaching practice (Gkonou \& Miller, 2019). In contrast, negative teacher behaviour is "uninformed" (p. 209) and stems from blame, exemption, and discipline.

Considering the importance of studying teacher psychology (Mercer \& Kostoulas, 2018), the recent "affective turn" in the interdisciplinary field of second language studies (Prior, 2019, p. 516), and the current growing interest in exploring language teachers' emotions (Benesch, 2018), we believe that by examining how language teachers construct themselves when working with students with dyslexia, we will further our understanding about teacher concerns and self-efficacy beliefs.

Drawing on the methodology and findings of previous studies that examined language teacher reflections on constructs of self and others (Gkonou \& Miller, 2019; Kayi-Aydar, 2015; Trent, 2012), this study explored the positioning of Croatian EFL teachers. We were also interested in whether this positioning would show teachingas-caring and emotion labour. The following questions were posed:

1. How do Croatian EFL teachers position students with dyslexia?

2. How do they position themselves towards this group of students?

3. How is teaching-as-caring revealed in their positioning?

4. To what extent does the teachers' caring attitudes involve emotion labour? 
Since this is the first study that enquired about language teacher positioning of learners with dyslexia, we could not form any hypotheses for the first and second research questions. In contrast, regarding questions three and four, based on previous findings on teacher positioning, we presumed that the participants' positioning would reveal teacher-as-caring and emotion labour. The former may stem from caring for an individual-in-need and being responsible for their progress in learning, whereas the latter may be related to teacher self-efficacy and working conditions.

\section{Methodology}

\section{Background Information}

The present study was part of a research project that aimed at investigating Croatian EFL teachers' knowledge and practice in the context of teaching students with dyslexia. The participants in the project were eight primary and eight secondary school EFL teachers working in mainstream state-financed schools in four regions in Croatia. Some findings have been reported based on the data collected in lesson observations and a semistructured interview (Kałdonek-Crnjaković \& Fišer, 2017).

\section{Participants}

The participants in this study were four Croatian EFL primary and six secondary school teachers. They were selected from a pool of 16 teachers that participated in the project based on a preliminary screening of interview transcripts. Information about the participants is summarised in Table 1. The participants' names are pseudonyms; they are listed in the order of appearance in the findings section of this paper.

\section{Table 1}

Information about the participants

\begin{tabular}{llclc}
\hline Pseudonym & Gender & \multicolumn{1}{c}{$\begin{array}{c}\text { Place of } \\
\text { work }\end{array}$} & $\begin{array}{c}\text { Work experience } \\
\text { in years }\end{array}$ \\
\hline 1 & Petar & Male & Primary school (PS) & 8 \\
2 & Iva & Female & PS & 1 \\
3 & Slaven & Male & Secondary school (SS) & 9 \\
4 & Mirna & Female & SS & 18 \\
5 & Marta & Female & SS & 14 \\
6 & Robert & Male & SS & 3 \\
7 & Sylvia & Female & SS & 8 \\
8 & Monika & Female & PS & 5 \\
9 & Dinka & Female & PS & 12 \\
10 & Renata & Female & SS & 19 \\
\hline
\end{tabular}

\section{Data Collection and Analysis}

The participants were interviewed using a five-part questionnaire with a range of open and closed questions and situational tasks. Interviews lasted between 45 and 75 minutes and were conducted in Croatian and English, depending on participants' preferences. The interview questions did not directly investigate teacher positioning. Teacher reflexive and interactive positioning was observed for ten project participants in the preliminary screening. Following the principles of the applied thematic analysis (Guest et al., 2012), we coded narrative accounts that showed how the participants positioned students with dyslexia and how they positioned themselves towards this group of students. Subsequently, we examined the selected narrative accounts to see whether teacher positioning revealed teaching-as-caring and emotion labour. The coding was performed in the following areas: (1) beliefs and opinions about students with dyslexia; (2) roles played and practices when teaching this group of students; (3) attitudes and practices that demonstrate caring when teaching students 
with dyslexia; and (4) expressing emotions when teaching this group of students. We extended the area of the analysis with the second examination of the transcript because we had noticed that the reflexive positioning of some teacher participants referred to all students in the class. Therefore, the coding also included the context of the whole classroom (inclusive practices). However, the codes emerged within the same accounts illustrating relational positioning, which revealed teaching-as-caring and emotion labour. The following themes emerged as a result of the analysis: (1) students with dyslexia as successful learners and teachers as supporters of students' effort; and (2) students as anxious and disengaged learners and teachers as those responsible for students' well-being. These themes relate to the first two research questions that enquired about teacher positioning. The evidence for research questions three and four were provided when discussing the findings within these two themes.

Next, to triangulate the data, and on the assumption that teacher positioning is analysed not only through the lens of conversations but also actions (Harré \& Moghaddam, 2015), including "physical cues" (Hazari et al., 2015 , p. 743), we revisited the notes taken during the lesson observations. The notes from the lesson observations constituted a complementary source of data to the findings yielded from the interview transcripts.

\section{Results}

\section{Theme 1: Students with Dyslexia as Successful Learners and Teacher Participants as Supporters of Students' Efforts}

Many participants voiced their positive opinions about students with dyslexia and believed that they could learn a foreign language successfully, regardless of the difficulties they experienced, which could be alleviated with adequate support from the teacher. Petar said that students with dyslexia "can perform really well in English" and stressed that "You just need to adopt an individual approach. It's all about the right support." Iva added that students with dyslexia could master English to the level comparable to their peers: "I think students with dyslexia can do as well as the other students. They can master all four language skills. They will struggle sometimes, but it's not important. You just need to support them." Slaven said that dyslexia "is maybe a difficulty, and you can see that students with dyslexia struggle, for example with writing. But I think it's different language perception. They see things different, and you need to take it into account when you support the student." Mirna recognised the difficulty in writing but strength in speaking skills in her student with dyslexia: "He struggles with writing; that's for sure. Reading is not so bad, but he is pretty good at speaking. When we do speaking activities, he is good, he talks and works in groups. I think he can be proficient in English. When you provide the right support, students with dyslexia can be proficient in English."

Mirna also positioned her student with dyslexia as an engaged learner when she said that "he talks and works in groups." In a similar vein, Marta viewed her students with dyslexia are hard-working and motivated to learn English. She recognised her students' effort by providing them with additional help and learning resources. Marta's response also indicates that she needs to devote extra teaching time. Her supportive attitude reveals that she cares about the success of all her learners, regardless of their specific needs: "You can tell they [students with dyslexia] are motivated to learn English and do well in English lessons. They work hard at home. They ask me for additional resources to do at home. I do my best to help them improve in English. I give them additional tasks, reading. Sometimes, I stay after the lessons to explain what they didn't understand during the lesson."

We also observed this caring attitude when Slaven told us that he supported students' efforts by recognising their individual strengths: "I give positive points for good performance; what the student is good at. For example, one of my students with dyslexia was good at comparing English and Croatian literature and I gave him a point for that."

In these narrative accounts, students with dyslexia were positioned as individuals who have their strengths and weaknesses; and teachers, in their ethic of care, need to providing support accordingly, recognising the individual profile of each learner. Robert said that "not every student is the same", and thus it is important to understand the difficulties they experience in a specific context: "This is why you need to check what they 
struggle with, for example, when they are doing different tasks." Yet, he also acknowledged that some teaching approaches might be inefficient, when he said, "Some things work, some don't."

Likewise, Sylvia talked about her continuous attempts to understand specific students' needs and how important it is for efficient support provisions. She enthusiastically commented on the approach she used when supporting her students with dyslexia in essay writing: "I always try to understand what specific problems they have and how I can help them. One of my students struggled with the structure of the essay, but I just explained it again on a one-to-one basis, and he started doing it correctly!"

The caring attitude of primary school teachers was revealed in their feelings of responsibility for enhancing students' motivation for learning English. They recognise effort, adjust teaching approaches, and provide accommodations for all students. Monika's aim is that her students with dyslexia develop a positive attitude towards English: "I use simple questions to motivate weaker students. I want them to answer the questions to show that they can say something in English. I don't want them to start hating English."

In contrast, Dinka involves all her students in classroom activities. She includes students with dyslexia even in the tasks that they may struggle with. She gave an example of spelling games and stressed that it was important to recognise an attempt: "This may not be by the rules, but I like to give a prize to pupils who guess the right spelling of the words. I reward them with an A grade, and then everyone tries to guess the right spelling of the word ... I hear all kinds of attempts, but for me, it’s important that my students take part in the lesson."

Petar told us about adjusting teaching materials and the importance of engaging parents. His attitude shows that supporting a student with dyslexia should go beyond the teaching process that happens in the classroom setting: "Teachers should see the student as an individual, use different resources depending on the students' needs, for example, eliminate busy pages for those with reading difficulties; parents should be included as well, for example, how they can support their child at home."

We gathered more evidence for these teachers' teaching-as-caring while observing their lessons. Slaven provided an additional explanation. Monika and Mirna differentiated questions and praised every attempt their students made. Dinka asked the class to spell the words they had learned in the previous lesson in their books then walked around the class and provided constructive feedback, whereas Petar stayed after his class and talked to the parent of his student with dyslexia, showing what materials had been covered in the class and commenting on the student's performance.

However, regarding accommodations, some participants believed that it was paramount to discuss their provision with students. Also, students with dyslexia should be given a choice as to whether to engage in classroom activities. Slaven provides "accommodations only if the student wants"; he thinks that "it's important because if you don't ask, the student can feel uncomfortable." Mirna, on the other hand, makes dictation optional in her class, and if the student decides to do so, she negotiates marking: "I don't force them to do dictation tasks if they don't wish. If they decide to write a dictation, I ask them if they are happy with the grade they got. If not, I don't write the grade down."

These narrative accounts show that students with dyslexia are seen as partners with whom the teacher should have an ongoing discussion about how and when specific needs should be accommodated. In contrast, the lack of such a partnership would show a careless teacher attitude.

Further on accommodations, some teacher participants stressed the importance of their purposefulness and beneficial effects. They talked about how certain accommodations might affect the student once they leave school. Mirna told us about her attitude on adjusting classroom activities. She thinks that focusing on listening and speaking may affect the performance of students with dyslexia on final school exams.

"I know that students with dyslexia should learn through listening and speaking, but in the real world, they need to read and write. I assess them orally when we do tasks in the classroom, but exams need to be done in writing, so I need to prepare them for that." 
Robert also thinks about his students beyond the classroom. He said: "I don't print work for my students with dyslexia on colour paper because no one outside the classroom would do it for them. I need to prepare them for what awaits them when they leave school." He added that it was important to help students with dyslexia develop effective strategies: "I usually use the resources that are already available. I want that my students can manage authentic materials. They have to come up with a strategy, how to handle the material if it is too difficult for them. This is what they will need to do when they leave school."

Mirna's and Robert's attitudes may seem severe and uninvolved, but it actually shows caring about students' success in the future, beyond the scope of the language learning curriculum. These teacher participants feel that by restricting accommodations, they prepare their students for what awaits them once they finish school; when they need to function in a less protective environment.

When talking about providing accommodations and making adjustments for students with dyslexia such as printing recourses on tinted paper or enlarging font size, many participants stressed financial issues. These issues, as expressed by Iva, bring about barriers to effective teaching: "I know that for some of my students a text with larger font size or on tinted paper would be beneficial, but my school doesn't provide paper other than white. We have a copy machine and a printer here in the school, but we can't use them, like, you know, for everyday stuff; and they are often jammed. It is so frustrating! If I want to do additional copying, I would need to pay for it myself. And it's not right. It's really disappointing."

Iva's narrative account shows that a lack of appropriate resources in the workplace may cost the teacher emotionally as it can be a source of disappointment and frustration. Iva is aware of the accommodations her students with dyslexia need, but her agency is limited by external factors. She could overcome this obstacle; however, she seems unwilling to use her private funds.

\section{Theme 2: Students as Anxious and Disengaged Learners and Teachers as Those Responsible for Students' Well-being}

Participants also recognised anxiety among their students with dyslexia. Petar, for example, talked about the physical signs of stress his student with dyslexia experienced at school and how he tried to mitigate it: "I can tell that school is stressful for him. For example, he bites his nails, he is silent during lessons, rarely smiles. He's shy, he doesn't have many friends. I try not to put too much pressure on him, but try to involve him in what we do in the classroom. Sometimes it works, sometimes not."

Marta also positions her student with dyslexia as anxious. She talked about how worried he was about his performance at school due to the pressure at home, and how she felt about this situation: "There is a lot of pressure at home. He is worried all the time and asks me how he can improve his grades. Sometimes, it is too much. I tell him he shouldn't be worrying so much because his grades are good. But his parents want 5s [the highest grade] in every subject. I can't always give him 5; it would be unfair towards other students."

Petar's and Marta's caring attitudes reveal their positioning; they feel responsible for mitigating the stress their students experience. Petar, on the one hand, does not pressure the student; on the other hand, he tries to involve the student in the class activities. Marta tries to convince her student that his grades showed that he was doing well in English. However, Marta seems to be paying an emotional cost. On the one hand, she sympathises with the student and recognises his learning success; on the other hand, she feels the pressure of being responsible for the student's good grades. In response, to maintain her integrity as a teacher who treats all students equally, she states that marking depends on performance.

Other teacher participants positioned themselves as responsible for students' well-being by creating a positive, comfortable, and inclusive atmosphere in the classroom. Slaven ensures his students with dyslexia feel comfortable, and in this way increases the quality of their performance: "I make sure the student feels comfortable before starting speaking. It's important because if he or she doesn't feel comfortable, they will make many mistakes, for example, in pronunciation, or get stuck and will not say anything."

Petar recognises that his students with dyslexia may struggle, but at the same time makes sure that they feel comfortable and encouraged to participate in classroom work: "It is important that students with dyslexia feel 
comfortable in the class. Even though they struggle with most of the things we do in the class, I try to encourage them to participate."

In the same vein, Renata believes that a positive atmosphere in the classroom will make the students more included and relaxed: "In general, the most important thing is that you create a positive atmosphere in the class so that the student doesn't feel excluded or stressed."

These inclusive practices were observed in the lesson these teachers taught. For example, Renata, having first praised good vocabulary use, encouraged her student with dyslexia to read her work aloud. Petar asked his student with dyslexia, who looked disengaged sitting in the back of the class, to come to the board and try to match the word with the picture once other students had volunteered to match other words with pictures. Petar also supported the student by directing him to the correct answer; he referred to the student's prior knowledge and the work other students had done. Petar commented on this situation in the interview by stressing the lack of voluntary participation in his student with dyslexia: "He [the student with dyslexia] needs to be asked. I mean, he won't raise his hand, come to the board on his own. I need to ask him to do so."

Disengagement among students with dyslexia can be regarded as laziness. When discussing participants' training needs, Marta, Renata, and Mirna said that many foreign language teachers had a negative attitude towards students with dyslexia and consider them 'lazy'. They suggested that future training should address such views by discussing what dyslexia is, how it affects learning, and how students with dyslexia can be helped:

Marta: "I would like to know more about what else I can do; how to help the student better so that teachers don't see them as lazy."

Renata: "Many of my colleagues think that students with dyslexia are lazy and they can't learn a foreign language. This is not right."

Mirna: "Also, it is important that all teachers know what dyslexia is and how it affects learning. A lot of teachers stigmatise dyslexics, call them lazy."

These teacher participants seem to engage in emotion labour. In light of ethical self-formation, they want to be able to provide more appropriate support to students with dyslexia. They also act as advocates for students with dyslexia. This shows their caring attitudes as they feel responsible for the fairer treatment of these students by other teachers.

On this occasion, Mirna, a secondary school teacher, also talked about her ten-year-old son, who is a learner with dyslexia. While she expresses sympathy for her son's language anxiety, she also appears disappointed and unsure when talking about approaches she uses to boost her son's confidence and when helping him revise lessons and do homework: "Now, he lacks motivation and this worries me. His grades could be better, and grades are important later when applying for a secondary school. I am trying to engage him in different activities when we revise lessons or do homework, but nothing seems to work. He is not lazy, but I think he's ashamed to use English; he is afraid of making mistakes. Sometimes I feel sorry for him. He compares himself with his mates in the class who are better at English, which is not right. I talk to him, but I think at this age, children don't want to listen to their parents. I'm trying to make him more confident, but I'm not sure if I'm doing it right. I need to know how to motivate him, how he can be more confident, how to teach him."

However, apart from expressing worries about her son's difficulties learning English, she also talked about hope in relation to her secondary school students' progress, attainment, and motivation for learning English: "When I look at my students with dyslexia, I believe one day he [Mirna's son] can learn English well. They are really good, especially speaking. They still struggle with learning English, but they make good progress. They are really motivated and want to work hard to get good grades. I believe I need to be patient." 


\section{Discussion}

In the first research question, we enquired about the participants' interactive positioning of students with dyslexia. We found that the teacher participants expressed many positive opinions about this group of students. They positioned them as hard-working, motivated, engaged, and able to learn English successfully. Yet, some participants also recognised anxiety and disengagement in their students with dyslexia. Similar stances have been expressed in the literature in the field. Many aspects of language learning can be challenging for learners with dyslexia (Crombie, 1997; Nijakowska, 2010). In turn, they display higher foreign language anxiety (Piechurska-Kuciel, 2008; Sparks \& Ganschow, 1991) and fewer positive motivational characteristics (Kormos \& Csizér, 2010). However, the display of affective factors in learners with dyslexia may be dependent on the teacher's attitude and the learning setting (Kormos et al., 2009) as well as the intensity of learning difficulties and the age of the learner (Nijakowska, 2010). This effect of age was observed in our study. Secondary school students were viewed as eager to learn, whereas a lack of motivation and disengagement was reported in primary school students. For example, in Petar's primary school lesson, the student with dyslexia seemed unwilling to voluntarily participate in classroom activities, which Petar commented on during the interview. Mirna talked about her son, a primary school student, who 'now' lacks motivation for learning English because of his learning difficulties and possible mistakes he may make when using the language, and compared him with her motivated and engaged secondary school students with dyslexia.

Although such disengagement and avoidance among learners with dyslexia may appear as laziness to teachers (Nijakowska, 2010), many of the participants in this study explicitly disagreed with this view referring to positioning their students with dyslexia as hard-working, motivated, and engaged. In this way, and in reference to our second research question that enquired about reflexive positioning, the teacher participants positioned themselves as advocates of students with dyslexia. Marta and Mirna pointed out that students' disengagement may be due to teachers' lack of agentic position that stems from a lack of knowledge of how dyslexia affects learning a foreign language and of effective teaching strategies. This lack of knowledge among pre- and inservice teachers was found by many large-scale studies (e.g., Fišer, 2019; Nijakowska, 2014), which consequently results in teacher low self-perceived efficacy and preparedness (Fišer, 2019; Kormos \& Nijakowska, 2017; Nijakowska et al., 2018).

Many participants recognised the importance of motivation for learning and engagement among their students with dyslexia. In their efforts to provide their students with dyslexia with appropriate support and create a comfortable and motivating learning environment, the participants opted for collaboration with their students. Hence, these teachers positioned themselves and positioned their students as partners; students were regarded as "relational" and "interdependent" individuals (Held, 2006, p. 46).

However, some teachers believed that their role regarding some types of support should be more leading for the sake of the student. By adopting such a stance, they resemble the attitude of the teacher in Reeve's study (2009), who believed that some accommodations might be disadvantageous for his students with limited English proficiency "because if they're really going to be part of this society, and they're really going to function in it" (Reeve, 2009, p. 38). Such an attitude may seem harsh, however, drawing on Kormos et al.'s study (2009), being strict and demanding was viewed by language learners with dyslexia as positive teacher characteristics; they were important for motivational teaching practices and the attribution of a supportive teacher.

In this way, the participants' behaviour appeared to be "enlightened" (Kormos \& Kontra, 2008, p. 209). Also, drawing on Yoon's view (2008), the participants maximised their students' participation and learning by assuming responsibility and having a positive attitude when responding to students' various needs. Limiting the provision of accommodations and alterations to learning resources and teaching approaches may also be interpreted as teaching-as-caring, yet only when justified within a specific context and when each student's needs are fully considered.

The participants also positioned themselves as teachers of all learners. Many teacher participants showed "responsiveness to need" and "cultivating caring relations [...] for the benefit of all" (Held, 2006, p. 15); thus their practices may be deemed inclusive, like the participants' in Kayi-Aydar's (2015) and Yoon's studies (2008), for example. This is best exemplified by the response of Petar, who said that "teachers should see the student as an individual, (and) use different resources depending on the students' needs". 
Assuming responsibility and caring for the well-being of students, however, incurred emotional costs for some teacher participants, confirming our presumption for the fourth research question. These costs seemed unnoticeable (Isenbarger \& Zembylas, 2006). This may be because the teacher participants experienced negative emotions when showing teaching-as-caring, when facing a dilemma, or when feeling the limitation of their agency. For example, Marta tried to balance the pressure from home and her student's worries against the ethical stance of treating all students fairly. Whereas Iva, similarly to teacher participants in Gkonou and Miller's study (2019), experienced emotion labour due to her working conditions. It is noteworthy that she recognised limitations to her agency in teaching-as-caring when working with students with dyslexia early in her teaching career. Consequently, her teacher immunity may potentially develop as "maladaptive" (Hiver \& Dörnyei, 2017, p. 405) and lead to burnout, which is experienced increasingly by language teachers worldwide (Gkonou \& Miller, 2019).

Many teacher participants also showed concern about their limited knowledge of effective teaching approaches. In their pursuit of becoming better teachers (Gkonou \& Miller, 2019), they want to provide students with dyslexia with more appropriate support. On the other hand, when an adopted strategy works, it leads to emotional rewards (Isenbarger \& Zembylas, 2006; Miller \& Gkonou, 2018). We observed this in Sylvia's enthusiastic comment on the effectiveness of the approach she used when teaching essay writing. This enthusiasm was also felt when Dinka, Marta, and Slaven talked about the learning efforts of their students with dyslexia and how they supported them.

In short, drawing on Benesch's recent view on emotion labour (2020), teacher participants' ambivalent emotions, when caring about their students' well-being and attempting to accommodate students' needs adequately in challenging working conditions, should not be regarded as a sign of "an inability to regulate one's emotions", but rather as "a signal of institutional inadequacy and therefore a springboard for activism" to ameliorate "unfair and unjust conditions" (Benesch, 2020, p. 37). Undoubtedly, these conditions may be alleviated by providing training opportunities that would help language teachers understand the effects of dyslexia on additional language learning and to learn about effective teaching approaches and accommodations that can be employed in a mainstream language classroom for students with dyslexia. As reported by Kormos and Nijakowska (2017), a high-quality training course on dyslexia and language teaching can help teachers alleviate their concerns, and develop more positive attitudes and higher self-confidence.

\section{Conclusion}

In this study, we aimed to investigate the positioning of Croatian primary and secondary language school teachers in the context of teaching EFL to students with dyslexia. We found that the teacher participants had a positive attitude towards learners with dyslexia. Their positioning showed teaching-as-caring, which supported our earlier assumptions. Most importantly, the participants' caring attitudes involved all learners, which shows that they are sensitive to various learner needs and willing to adapt their teaching approaches and provide adequate accommodations. Our hypothesis for the last research question was also confirmed because the participants' teaching-as-caring resulted in emotion labour, with both emotional costs and rewards, as indicated in the literature on the topic.

Although the findings presented in this paper reflect reflexive and interactive positioning by teachers, the topic has not been fully explored because the scope of the project within which the interviews were recorded did not explicitly seek to investigate teacher positioning, teaching-as-caring, and emotion labour. This may be considered a limitation of the present study. A study designed to directly investigate EFL teacher positioning in the context of teaching learners with dyslexia could provide more complex data, and consequently allow for more profound analysis. Therefore, the findings of the present study should be interpreted with caution. Potential differences among teacher participants related to cultural and educational diversity would also be worth investigating. Future research could also simultaneously explore diverse teaching settings, for example, one-to-one instruction and the mainstream classroom from the learner and teacher perspective considering their agency.

The indirect investigation of positioning, teaching-as-caring, and emotion labour is what distinguishes this study from other research that directly sought to explore these issues. This study showed that teachers need to 
talk about their emotions related to teaching students with dyslexia. We hope that our results yielded from qualitative data have complemented previous research findings and added to the discussion on language teacher agency in the context of teaching students with dyslexia by showing what may affect it and what varied and complex emotions teachers may experience. Also, teaching-as-caring and teacher emotion labour in this paper indicate the importance of teacher emotional well-being. Teacher professional well-being is closely related to teacher ethical self-formation; therefore, it should be considered one of the current priorities in language teaching and learning.

\section{Acknowledgements}

We want to thank the anonymous reviewers for their valuable comments about the first draft of the article that allowed us to improve the quality of this paper.

\section{Declaration of Competing Interest}

None declared.

\section{References}

Acheson, K., Taylor, J., \& Luna, K. (2016). The burnout spiral: The emotion labor of five rural U.S. foreign language teachers. Modern Language Journal, 100(2), 522-537. https://doi.org/10.1111/modl.12333

Benesch, S. (2012). Considering emotions in critical English language teaching: Theories and praxis. Routledge.

Benesch, S. (2017). Emotions and English language teaching: Exploring teachers' emotion labor. Routledge.

Benesch, S. (2018). Emotions as agency: Feeling rules, emotion labor, and English language teachers' decisionmaking. System, 79, 60-69. https://doi.org/10.1016/j.system.2018.03.015

Benesch, S. (2020). Emotions and activism: English language teachers' emotion labor as responses to institutional power. Critical Inquiry in Language Studies, 17(1), 26-41. https://doi.org/10.1080/15427587.2020.1716194

Chernobilsky, E., Kosheleva, E., \& Kobzeva, N. (2015). Student views of a caring teacher in an undergraduate English language classroom in Russia. Procedia - Social and Behavioral Sciences, 166, 303-308. https://doi. org/10.1016/j.sbspro.2014.12.528

Collins, S., \& Ting, H. (2014). The complexity of care. Complicity, 11, 5-19. https://doi.org/10.29173/cmplct21452

Crombie, M. (1997). The effects of specific learning difficulties (dyslexia) on the learning of a foreign language in school. Dyslexia, 3(1), 27-47. https://doi.org/10.1002/(SICI)1099-0909(199703)3:1<27::AIDDYS43>3.0.CO;2-R

Davies, B., \& Harré, R. (1990). Positioning: The discursive production of selves. Journal for the Theory of Social Behaviour, 20(1), 43-63. https://doi.org/10.1111/j.1468-5914.1990.tb00174.x

Fišer, Z. (2019). Kompetencije budućih i sadašnjih nastavnika stranih jezika u hrvatskim školama za poučavanje učenika s disleksijom [Competence of Croatian pre- and in-service teachers of foreign languages in teaching students with dyslexia] [Unpublished doctoral dissertation]. University of Zagreb.

Gkonou, Ch., \& Miller, E. R. (2019). Caring and emotional labour: Language teachers' engagement with anxious learners in private language school classrooms. Language Teaching Research, 23(3), 372-387. https://doi. org/10.1177/1362168817728739

Guest, G., MacQueen, K. M., \& Namey, E. E. (2012). Applied thematic analysis. Sage Publications.

Hargreaves, A. (2000). Mixed emotions: Teachers' perceptions of their interactions with students. Teaching and Teacher Education, 16(8), 811-826. https://doi.org/10.1016/S0742-051X(00)00028-7

Harré, R., \& Moghaddam, F. (2015). Positioning theory and social representations. In The Cambridge Handbook of Social Representations (pp. 224-233). Cambridge University Press.

Harré, R., \& van Langenhove, L. (1999). The dynamics of social episodes. In R. Harré, \& L. V. Langenhove (Eds.), Positioning theory: Moral contexts of intentional action (pp. 1-13). Blackwell.

Hazari, Z., Cass, C., \& Beattie, C. (2015). Obscuring power structures in the physics classroom: Linking teacher positioning, student engagement, and physics identity development. Journal of Research in Science Teaching, 52(6), 735-762. https://doi.org/10.1002/tea.21214

Held, V. (2006). The ethics of care: Personal, political, and global. Oxford University Press. 
Hiver, P., \& Dörnyei, Z. (2017). Language teacher immunity: A double-edged sword. Applied Linguistics, 38(3), 405-423. https://doi.org/10.1093/applin/amv034

Hochschild, A. (1983). The managed heart: Commercialization of human feeling. University of California Press.

Isenbarger, L., \& Zembylas, M. (2006). The emotional labour of caring in teaching. Teaching and Teacher Education, 22(1), 120-134. https://psycnet.apa.org/doi/10.1016/j.tate.2005.07.002

Kałdonek- Crnjaković, A., \& Fišer, Z. (2017). 'Dyslexia-friendly' approaches in the teaching practice of Croatian English as a foreign language (EFL) teachers. In S. Letica Krevelj, \& R. Geld (Eds.), UZRT 2016 Empirical Studies in Applied Linguistics (pp. 139-149). FF Press.

Kayi-Aydar, H. (2014). Social positioning, participation, and second language learning: Talkative students in an academic ESL classroom. TESOL Quarterly, 48(4), 686-714. https://doi.org/10.1002/tesq.139

Kayi-Aydar, H. (2015). Teacher agency, positioning, and English language learners: Voices of pre-service classroom teachers. Teaching and Teacher Education, 45, 94-103. https://doi.org/10.1016/j.tate.2014.09.009

Kayi-Aydar, H. (2019). Positioning theory in applied linguistics: Research design and applications. Springer.

Kayi-Aydar, H., \& Miller, E. R. (2018) Positioning in classroom discourse studies: A state-of-the-art review. Classroom Discourse, 9(2), 79-94. https://doi.org/10.1080/19463014.2018.1450275

King, J. (2015). 'It's time, put on the smile, it's time!': The emotional labour of second language teaching within a Japanese university. In C. Gkonou, C., D. Tatzl, \& S. Mercer (Eds.), New directions in language learning psychology (pp. 97-112). Springer.

Kormos, J. (2017). The second language processes of students with specific learning difficulties. Routledge.

Kormos, J., \& Csizér, K. (2010). A comparison of the foreign language learning motivation of Hungarian dyslexic and non-dyslexic students. International Journal of Applied Linguistics, 20(2), 232-250. https://doi. org/10.1111/j.1473-4192.2009.00247.x

Kormos, J., Csizér, K., \& Sarkadi, A. (2009). The language learning experiences of students with dyslexia: Lessons from an interview study. Innovation in Language Learning and Teaching, 3(2), 15-130. https://doi. org/10.1080/17501220802638306

Kormos, J, \& Kontra, E. H. (2008). Hungarian teachers' perceptions of dyslexic language learners. In J. Kormos, \& E. H. Kontra (Eds.), Language learners with special needs: An international perspective (pp. 189-213). Multilingual Matters.

Kormos, J., \& Nijakowska, J. (2017). Inclusive practices in teaching students with dyslexia: Second language teachers' concerns, attitudes and self-efficacy beliefs on a massive open online learning course. Teaching and Teacher Education, 68, 30-41. https://doi.org/10.1016/j.tate.2017.08.005

Kormos, J., \& Smith, M. A. (2012). Teaching languages to students with specific learning differences. Multilingual Matters.

Koster, Sh. (2011). The self-managed heart: Teaching gender and doing emotional labour in a higher education institution. Pedagogy, Culture \& Society, 19(1), 61-77. https://doi.org/10.1080/14681366.2011.548988

Kumaravadivelu, B. (2012). Language teacher education for a global society: A modular model for knowing, analyzing, recognizing, doing, and seeing. Routledge.

Lantolf, J., \& Thorne, S. L. (2007). Sociocultural theory and second language learning. In. B. van Patten, \& J. Williams (Eds.), Theories in second language acquisition (pp. 201-224). Lawrence Erlbaum.

Mercer, S., \& Kostoulas, A. (2018). Introduction to language teacher psychology. In S. Mercer, \& A. Kostoulas (Eds.), Language teacher psychology (pp. 1-17). Multilingual Matters.

Mercer, S., Oberdorfer, P. \& Saleem, M. (2016). Helping language teachers to thrive: Using positive psychology to promote teachers' professional well-being. In D. Gabryś-Barker, \& D. Gałajda (Eds.), Positive psychology perspectives on foreign language learning and teaching (pp. 213-229). Springer International Publishing.

Miller, E. R., \& Gkonou, C. (2018). Language teacher agency, emotion labor and emotional rewards in tertiarylevel English language programs. System, 79, 49-59. https://doi.org/10.1016/j.system.2018.03.002

Nijakowska, J. (2010). Dyslexia the foreign language classroom. Multilingual Matters.

Nijakowska, J. (2014). Dyslexia in the European EFL teacher training context. In M. Pawlak, \& L. Aronin (Eds.), Essential topics in applied linguistics and multilingualism (pp. 129-156). Springer.

Nijakowska, J., Tsagari, D., \& Spanoudis, G. (2018). English as a foreign language teacher training needs and perceived preparedness to include dyslexic learners: The case of Greece, Cyprus and Poland. Dyslexia, 24(4), 357-379. https://doi.org/10.1002/dys.1598

Piechurska-Kuciel, E. (2008). Input, processing and output anxiety in students with symptoms of developmental dyslexia. In J. Kormos, \& E. H. Kontra (Eds.), language learners with special needs. An International Perspective (pp. 86-109). Multilingual Matters.

Prior, M.T. (2019). Elephants in the room: An 'affective turn,' or just feeling our way?" Modern Language Journal, 
103(2), 516-527. https://doi.org/10.1111/modl.12573

Reeves, J. (2009). Teacher investment in learner identity. Teaching and Teacher Education, 25(1), 34-41. https:// doi.org/10.1016/j.tate.2008.06.003

Sabat, S. R. (2003). Malignant positioning and the predicament of people with Alzheimer's disease. In R. Harré \&, F. M. Moghaddam (Eds.), The self and others: Positioning individuals and groups in personal, political, and cultural contexts (pp. 85-98). Praeger.

Sparks, R. L., \& Ganschow, L. (1991). Foreign language learning differences: Affective or native language aptitude differences? Modern Language Journal, 75(1), 3-16. https://doi.org/10.2307/329830

S $\oslash$ reide, G. E. (2006). Narrative construction of teacher identity: positioning and negotiation. Teachers and Teaching: Theory and Practice, 12(5), 527-547. https://doi.org/10.1080/13540600600832247

Trent, J. (2012). The discursive positioning of teachers: Native-speaking English teachers and educational discourse in Hong Kong. TESOL Quarterly, 46(1), 104-126. https://doi.org/10.1002/tesq.1

van Langenhove, L., \& Harré, R. (1999). Introducing positioning theory.In R. Harré, \& L. van Langenhove (Eds.), Positioning theory: Moral contexts of intentional action (pp. 14-31). Blackwell.

van Lier, L. (2008). Agency in the classroom. In J. P. Lantolf, \& M. E. Poehner (Eds.), Sociocultural theory and the teaching of second languages (pp 163-186). Equinox.

White, C.J. (2018). Language teacher agency. In Mercer, S., \& Kostoulas, A. (Eds.). Language teacher psychology (pp. 196-210). Multilingual Matters.

Yoon, B. (2008). Uninvited guests: The influence of teachers' roles and pedagogies on the positioning of English language learners in the regular classroom. American Educational Research Journal, 45(2), 495-522. https:// doi.org/10.3102\%2F0002831208316200

Zembylas, M. (2002). "Structure of feeling" in curriculum and teaching: Theorizing the emotional rules. Educational Theory, 52(2), 187-208. https://doi.org/10.1111/j.1741-5446.2002.00187.x 